\title{
Supramolecular complexes of cobalt(II), manganese(II) and cadmium(II) with bis(terpyridine) ligand as novel luminescent materials
}

\author{
Monika Wałęsa-Chorab, Adam Gorczyński, Damian Marcinkowski, Zbigniew Hnatejko, \\ Violetta Patroniak* \\ "Adam Mickiewicz University, Faculty of Chemistry, Grunwaldzka 6, 60-780 Poznań, Poland, e-mail: violapat@amu.edu.pl
}

\begin{abstract}
Self-assembly of $\mathrm{N}_{6}$-donor bis(terpyridine) ligand $\mathbf{L}$ with transition metal ions: $\mathrm{Co}(\mathrm{II}), \mathrm{Mn}(\mathrm{II})$ and $\mathrm{Cd}(\mathrm{II})$ leads to a formation of three kinds of supramolecular complexes. In the electronic absorption and emission spectra of supramolecular complexes additional bands were observed what was ascribed to the coordination of ligand molecules to metal ions. Luminescence properties of these complexes strongly depend on the kind of metal ions and counter ions. The effective blue luminescence was observed in the case of $\mathrm{Mn}(\mathrm{II})$ and $\mathrm{Cd}(\mathrm{II})$ complexes in which all $\mathrm{N}$-donor atoms of ligand molecules coordinate with the metal center.
\end{abstract}

Keywords: luminescence, supramolecular complexes, transition metal ions.

\section{INTRODUCTION}

In recent years, the study of photoluminescent supramolecular complexes has been attractive mainly due to their many potential applications. One of the most important physicochemical properties of supramolecular complexes are their luminescence properties ${ }^{1}$. Transition metal complexes which exhibit emission of light are attractive materials for the construction of organic light-emitting diodes $^{2-6}$. Particularly $\mathrm{d}^{\mathbf{1 0}}$ metal ions, such as $\mathrm{Zn}(\mathrm{II})$ and $\mathrm{Cd}(\mathrm{II})$, are suitable for the construction of luminescent coordination complexes ${ }^{7-9}$. Such compounds often have selective properties and can be used as sensors for the detection of different anions or molecules ${ }^{\mathbf{1 0}, \mathbf{1 1}}$.

Previously we described synthesis of $\mathrm{N}_{6}$-donor ligand 6',6"-(2-phenylpyrimidine-4,6-diyl)bis(6-methyl-2,2'-bipyridine) and its self-assembly with transition metal ions ${ }^{12,13}$. Bis(terpyridine) ligand $\mathbf{L}$, obtained via Stille-type coupling reaction, in reactions with transition metal ions forms four types of supramolecular complexes (Scheme 1).

Complexes were characterized by spectroscopic and analytical methods and, in few cases, by X-ray analysis. Reaction of $\mathbf{L}$ with silver(I) ions leads to obtaining dinuclear helical complex, which is known as an active photocatalyst of degradation of organic pollution in water ${ }^{13}$. Structures of complexes with manganese(II), cobalt(II) and cadmium(II) ions strongly depend on the kind of anions. In the reactions of halide salts (chloride and bromide) mononuclear complexes have been obtained in which one $\mathbf{N}_{3}$-donor subunits of $\mathbf{L}$ does not take part in coordination with metal center. In the presence of nitrate anions dinuclear baguette complexes were formed. When reactions were carried out in the presence of perchlorate anions trinuclear complexes have been obtained. Cobalt(II) and manganese(II) complexes show interesting magnetic properties ${ }^{12}$. Some platinum(II) complexes with terpyridine ligand exhibit luminescence highly dependent on the temperature, type of counter ions, and solvents used for crystallization ${ }^{14}$.

Herein we describe luminescence properties of mono-, di- and trinuclear complexes of $\mathrm{Mn}(\mathrm{II})(\mathbf{1}-\mathbf{4}), \mathrm{Co}(\mathrm{II})$ $(5-7)$ and $\mathrm{Cd}(\mathrm{II})(\mathbf{8}, \mathbf{9})$ complexes and the influence of different guests on their emission behaviour.

\section{RESULTS AND DISCUSSION}

Due to the solubility the electronic absorption and emission properties of ligand were studied in dichloromethane, while the electronic spectra of all metal complexes were recorded in acetonitrile solution. The spectroscopic data of dilute $\left(\sim 1 \times 10^{-5} \mathrm{M}\right)$ solutions are given in Table 1.

In view of the data obtained for the complexes from IR and elementary analyses, further corroborated by X-ray

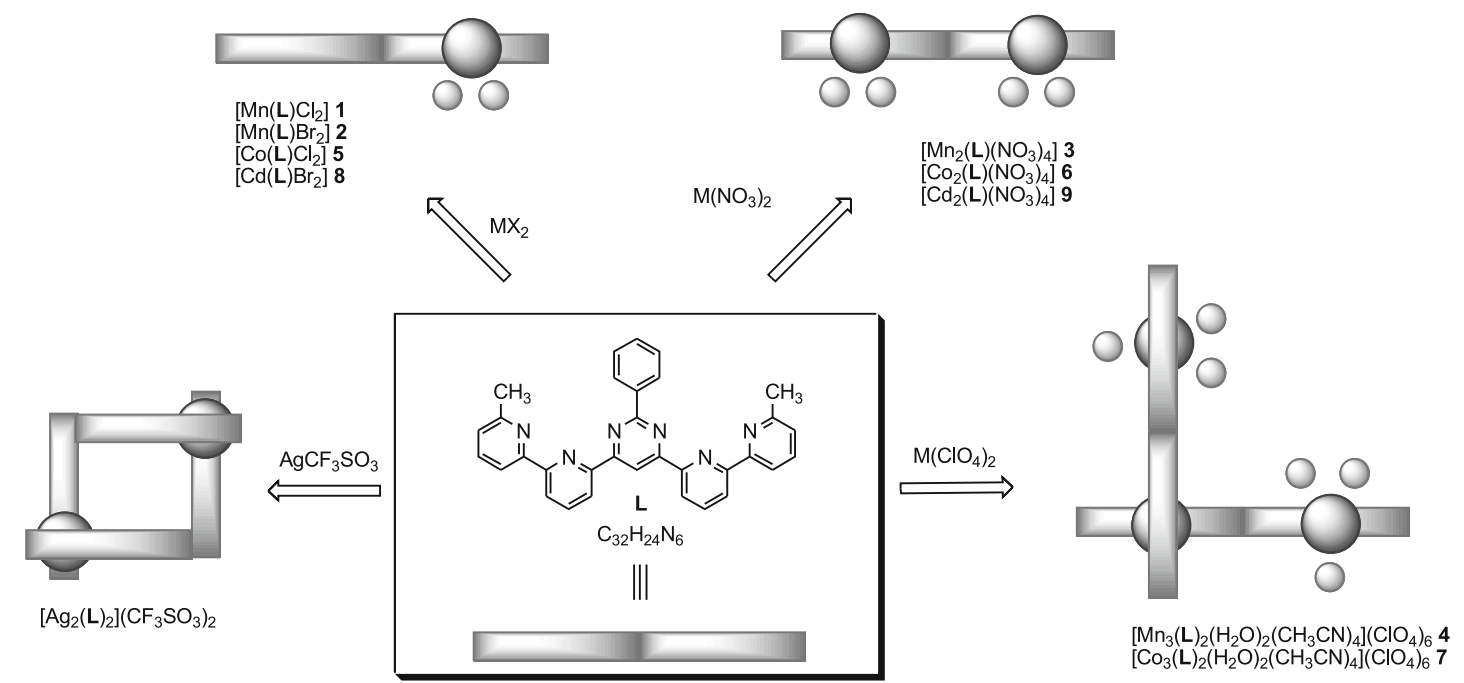

Scheme 1. Schematic representation of self-assembly of ligand $\mathbf{L}$ with transition metal ions 
Table 1. Absorption and emission data for the studied systems

\begin{tabular}{|l|c|c|}
\hline Compound & $\lambda_{\max .}[\mathrm{nm}]\left(\varepsilon\left[\cdot 10^{4} \mathrm{~mol}^{-1} \cdot \mathrm{dm}^{3} \cdot \mathrm{cm}^{-1}\right]\right)$ & $\lambda_{\mathrm{ex}} / \lambda_{\mathrm{em}}[\mathrm{nm}]$ \\
\hline $\mathbf{L}$ & $230.5(8.4) ; 280.0(3.8) ; 320.0(1.4) ; 334.0(0.9)$ & $334 / 374$ \\
\hline$\left[\mathrm{Mn}(\mathrm{L}) \mathrm{Cl}_{2}\right]$ 1 & $238.0(2.6) ; 277.5(2.5) ; 337.0(0.7)$ & $335 / 374$ \\
\hline$\left[\mathrm{Mn}(\mathrm{L}) \mathrm{Br}_{2}\right] \mathbf{2}$ & $278.0(1.3) ; 335.0(0.6)$ & $331 / 370$ \\
\hline$\left[\mathrm{Mn}_{2}(\mathrm{~L})\left(\mathrm{NO}_{3}\right)_{4}\right]$ 3 & $238.5(4.6) ; 276.5(5.5) ; 334.5(1.7)$ & $335 / 478$ \\
\hline$\left[\mathrm{Mn}_{3}(\mathrm{~L})_{2}\left(\mathrm{CH}_{3} \mathrm{CN}\right)_{4}\left(\mathrm{H}_{2} \mathrm{O}\right)_{2}\right]\left(\mathrm{ClO}_{4}\right)_{6} \mathbf{4}$ & $237.0(5.8) ; 278.0(5.1) ; 343.5(3.0)$ & $342 / 478$ \\
\hline$\left[\mathrm{Co}(\mathrm{L}) \mathrm{Cl}_{2}\right] \mathbf{5}$ & $237.5(1.7) ; 277.0(1.6) ; 335.0(0.5)$ & $335 / 362$ \\
\hline$\left[\mathrm{Co}_{2}(\mathrm{~L})\left(\mathrm{NO}_{3}\right)_{4}\right] \mathbf{6}$ & $281.5(3.0) ; 351.0(2.7)$ & $351 / 394$ \\
\hline$\left[\mathrm{Co}_{3}(\mathrm{~L})_{2}\left(\mathrm{CH}_{3} \mathrm{CN}\right)_{4}\left(\mathrm{H}_{2} \mathrm{O}\right)_{2}\right]\left(\mathrm{ClO}_{4}\right)_{6} \mathbf{7}$ & $235.5(8.0) ; 277.5(6.2) ; 347.0(4.0)$ & $347 / 389$ \\
\hline$\left[\mathrm{Cd}_{2}(\mathbf{L}) \mathrm{Br}_{2}\right] \mathbf{8}$ & $276.0(2.3) ; 331.0(1.2)$ & $331 / 362$ \\
\hline$\left[\mathrm{Cd}_{2}(\mathrm{~L})\left(\mathrm{NO}_{3}\right)_{4}\right] \mathbf{9}$ & $278.0(2.4) ; 346.0(2.5)$ & $346 / 471$ \\
\hline
\end{tabular}

diffraction solid state structure studies of 4,5 and $\mathbf{6}^{\mathbf{1 2}}$, we have decided to investigate their behavior upon UV-Vis irradiation not only to determine the absorptive-emissive properties they display, but to essentially confront the hypothesis of the solely counterion-dependent self-assembly process.

The electronic absorption spectra in the UV region showed bands typical of $\pi-\pi^{*}$ ligand-based transitions (Table 1, Fig. 1) ${ }^{15}$. The latter one is found for all the investigated compounds, irrespective of their nuclearity nor the chosen metal ion (Fig. 1), manifested however by minute hipsochromic shifts (excluding $\mathbf{6}$ which is batochromic).

An additional, lower in energy, absorption band is visible upon coordination, particularly well developed for 4, 6, 7, 9 and macroscopically indicated by orange-yellow color of samples due to partial overlap with Vis region. Worth noting is the fact, that mononuclear complexes $(\mathbf{1}, \mathbf{2}, \mathbf{5}$ and $\mathbf{8}$ ) (main point of reference being $\mathbf{5}$ ) do
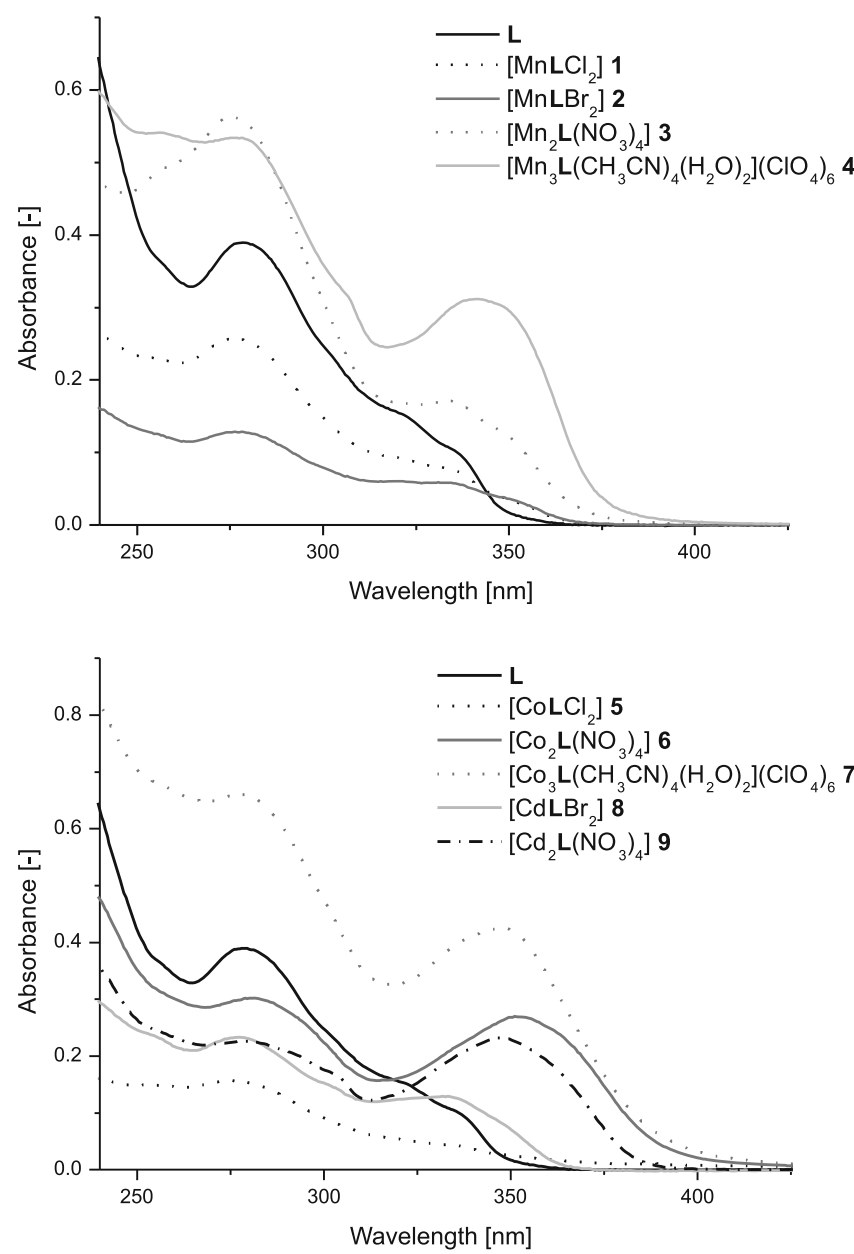

Figure 1. Absorption spectra of $\mathbf{L}$ and its complexes of $\mathrm{Mn}(\mathrm{II})$, $\mathrm{Co}(\mathrm{II})$ and $\mathrm{Cd}(\mathrm{II})$ ions not exhibit the aforementioned bands or their molar extinction coefficients are significantly lower.

Luminescence data comprise wavelengths at which complexes were excited together with maxima where the emission was the most intensive are listed in Table 1. Ligand $\mathbf{L}$ and metal complexes showed luminescence bands centered around $370 \mathrm{~nm}$ when irradiated by UV light. This suggest that the emission is mainly ligand-based. The ligand-based luminescence intensity of compounds as well as the shape of spectra depends on the complexing agent - both the type of metal ions and the kind of anions. The ligand $\mathbf{L}$ and compounds 1, 2, 5 and $\mathbf{8}$ show the UV-Vis spectra with bands in the UV region centered at 278 and about $335 \mathrm{~nm}$. On the excitation of the samples at both absorption bands, the same emission wavelengths in the emission spectra are observed. The higher values of emission intensity were measured for the lower energy absorption band.

In contrast to the complexes of $\mathrm{Co}(\mathrm{II})$ ions, additional broad bands with the maxima in the 470-490 $\mathrm{nm}$ region, are observed for the solutions of complexes 3,4 and 9 respectively (cf. Table 1) (Fig. 2). The photoluminescence spectra of $\mathbf{4}$ contain one strong emission band with the maximum at $483 \mathrm{~nm}$ and two weak peaks at 382 and $364 \mathrm{~nm}\left(\lambda_{\mathrm{ex}}=342 \mathrm{~nm}\right)$ (Fig. 2b), while 3 exhibit three emission maxima at 483, 373 and $364 \mathrm{~nm}$ and $\mathbf{9}$ - two maxima at 468 and $375 \mathrm{~nm}$ (Fig. 2c). The Co(II) ions just produce a quenching of the emission bands in the UV region of spectrum. As follows from the presented results the luminescence behaviour of the cadmium(II) and manganese(II) complexes are similar. With reference to the previous spectroscopic work on the luminescence of the $\mathrm{Cd}(\mathrm{II})$ complexes observed in these systems luminescence in UV region of spectrum is assigned to intraligand $\pi-\pi^{*}$ transitions, when the blue luminescence is related to the charge transfer transitions ${ }^{16,17}$.

The blue luminescent materials are important for the production of displays. Efficient, blue luminescence was observed for $\mathbf{4}$ and $\mathbf{9}$ complexes due to the metal centers and different types of coordination structures. Figure 2c shows that complexes of $\mathrm{Mn}$ (II) and $\mathrm{Cd}(\mathrm{II})$ type $\left[\mathrm{M}_{3}(\mathbf{L})_{2}\left(\mathrm{CH}_{3} \mathrm{CN}\right)_{4}\left(\mathrm{H}_{2} \mathrm{O}\right)_{2}\right]\left(\mathrm{ClO}_{4}\right)_{6}$ have better emission properties then mono- and dinuclear complexes containing the same metal ions. In these complexes the metal ions are unequal in binding mode. The central metal ion is coordinated by six nitrogen atoms from two different ligand molecules. Two other metal ions are coordinated by six nitrogen atoms of ligands and two acetonitrile and one water molecules ${ }^{12}$. When in coordination of the metal ions are involved $\mathrm{NO}_{3}{ }^{-}$anions, as in complex $\mathbf{3}$, the lower intensity of emission was observed. In the presence of halide ions in the structure of the metal complexes, the 
a)
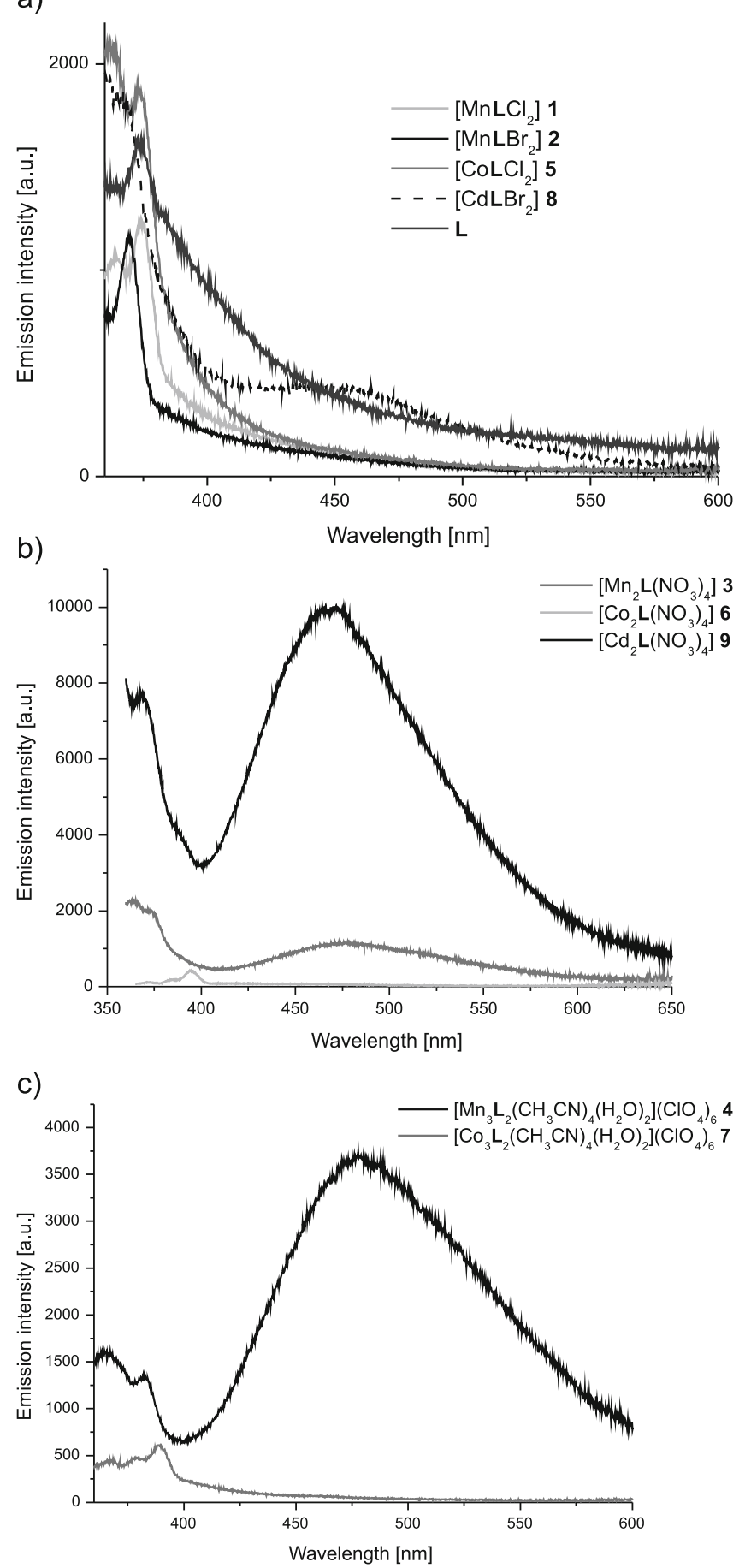

Figure 2. Emission spectra of ligand $\mathbf{L}$ and mono- (a) di- (b) and trinuclear (c) complexes

blue luminescence was not observed in $\mathbf{1}$ and $\mathbf{2}$, however a very weak luminescence was reported in [8].

Previously we reported that luminescence properties of $\mathrm{Mn}(\mathrm{II})$ and $\mathrm{Zn}(\mathrm{II})$ complexes with terpyridine ligand strongly depend on the kind of anions present in complex $x^{6}$. We have found a similar dependance in the case of these studies. It was found that in order for the latter to become not only present but also to be significant in terms of luminescent properties, the following requirements must be fulfilled: (i) counterions should be perchlorate or nitrate ions (chloride and bromide anions quench emission properties), (ii) templating metal ion must not be an inherent emission quencher. The first condition eliminates mononuclear $(\mathbf{1}, \mathbf{2}, \mathbf{5})$ complexes, which actually lack the long-wave band, whereas its intensity for $\mathbf{8}$ is substantially diminished and shallow i.e. even weaker than the one sole $\mathbf{L}$ exhibits (Fig. 2). The second stipulation explains why di- (6) and trinuclear (7) cobalt complexes lack the exclusive, lower in energy band. What is more, they make coordinated ligand molecule an order of magnitude weaker emitter than the sole $\mathbf{L}$. In accordance with the aforementioned terms, one may conclude that the remaining compounds $(\mathbf{3}, \mathbf{4}$ and $\mathbf{9})$ should enhance ligands emission in the visible region and indeed it is true. Complexes with Co(II) ions (which are luminescence quenchers) and halogen complexes of $\mathrm{Mn}(\mathrm{II})$ and $\mathrm{Cd}(\mathrm{II})$ shown only the ligand-based luminescence with different intensity.

\section{EXPERIMENTAL SECTION}

Metal salts were used without further purification as supplied from Aldrich. Syntheses and characterization of the ligand $\mathbf{L}$ and its complexes [ $\mathrm{Mn}_{3}(\mathbf{L})_{2}\left(\mathrm{CH}_{3} \mathrm{CN}\right)_{4}\left(\mathrm{H}_{2} \mathrm{O}\right)_{2}$ ] $\left(\mathrm{ClO}_{4}\right)_{6} \mathbf{4},\left[\mathrm{Co}(\mathbf{L}) \mathrm{Cl}_{2}\right] \mathbf{5}$ and $\left[\mathrm{Co}_{2}(\mathbf{L})\left(\mathrm{NO}_{3}\right)_{4}\right] \mathbf{6}$ were described before ${ }^{12}$. ESI mass spectra for acetonitrile solutions $\sim 10^{-4} \mathrm{M}$ were measured using a Waters Micromass ZQ spectrometer. Microanalysis was obtained using a Vario EL III CHN element analyzer. The IR spectra were obtained with a Bruker FT-IR IFS 66/s spectrometer and peak positions are reported in $\mathrm{cm}^{-1}$. All absorption spectra were recorded with a Shimadzu UV-2401PC spectrophotometer, between 200 and 800 $\mathrm{nm}$, in $10 \times 10 \mathrm{~mm}$ quartz cells using $\sim 1 \times 10^{-5} \mathrm{M}$ solutions with respect to the metal ion. Emission spectra were measured at room temperature on a Hitachi F7000 fluorescence spectrophotometer with an excitation and an emission slits at $5 \mathrm{~nm}$.

\section{Synthesis of complexes}

All complexes have been obtained in the same way. To a solution of $\mathbf{L}(165.0 \mathrm{mg}, 0.4 \mathrm{mmol})$ in mixture $\mathrm{CH}_{2} \mathrm{Cl}_{2} /$ $\mathrm{CH}_{3} \mathrm{CN}$ (9:1) appropriate metal salt $(0.4 \mathrm{mmol})$ was added. The solutions were mixed at room temperature for $48 \mathrm{~h}$ under the normal atmosphere. The complexes were isolated as stable solids by evaporation of the solvent and recrystallization of the residue from the minimum volume of acetonitrile by the gradual addition of ethyl ether.

$\left[\mathrm{Mn}(\mathbf{L}) \mathrm{Cl}_{2}\right]$ 1: Yellow solid was obtained with $75 \%$ yield. ESI-MS: $\mathrm{m} / \mathrm{z}(\%)=600(10)\left[\mathrm{Mn}(\mathbf{L}) \mathrm{Cl}\left(\mathrm{H}_{2} \mathrm{O}\right)\right]^{+}, 582(5)$ $[\mathrm{Mn}(\mathbf{L}) \mathrm{Cl}]^{+}, 515(20)[\mathrm{Na}(\mathbf{L})]^{+}, 273(10)[\mathrm{Mn}(\mathbf{L})]^{2+} . \mathrm{IR}$ $(\mathrm{KBr}): v=v(\mathrm{C}-\mathrm{H})_{\mathrm{ar}}$ 3109, 3090, 3065; $v_{\mathrm{s}}\left(\mathrm{CH}_{3}\right) 2923$; $v(\mathrm{C}=\mathrm{C}) 1597,1567,1533,1482,1469 ; v(\mathrm{C}=\mathrm{N}) 1440$, $1386,1364,1292,1246 ; \delta\left(\mathrm{CH}_{3}\right) 1325 ; \mathrm{e}(\mathrm{C}-\mathrm{H}) 1185$, 1155, 1077, 1019; $\gamma(\mathrm{C}-\mathrm{H})$ 998, 920, 829, 808, 793, 763, 700, $652 \mathrm{~cm}^{-1}$. Anal. Calcd. (\%) for $\left[\mathrm{Mn}\left(\mathrm{C}_{32} \mathrm{H}_{24} \mathrm{~N}_{6}\right) \mathrm{Cl}_{2}\right]$ (618.42): C, 62.15; H, 3.91; N, 13.59. Found: C, 62.20; $\mathrm{H}, 3.85 ; \mathrm{N}, 13.65$.

$\left[\mathrm{Mn}(\mathbf{L}) \mathrm{Br}_{2}\right]$ 2: Yellow solid was obtained with $63 \%$ yield. ESI-MS: $\mathrm{m} / \mathrm{z}(\%)=645(10)\left[\mathrm{Mn}(\mathrm{L}) \mathrm{Br}\left(\mathrm{H}_{2} \mathrm{O}\right)\right]^{+}$, 627 (40) $[\mathrm{Mn}(\mathbf{L}) \mathrm{Br}]^{+}, 493(70)[\mathbf{L}+\mathrm{H}]^{+}, 515(100)$ $[\mathrm{Na}(\mathbf{L})]^{+}, 274(30)[\mathrm{Mn}(\mathbf{L})]^{2+}$. IR $(\mathrm{KBr}): v=v(\mathbf{C}-\mathrm{H})_{\mathrm{ar}}$ 3139, 3098, 3070; $v_{\text {as }}\left(\mathrm{CH}_{3}\right)$ 2964; $v_{\mathrm{s}}\left(\mathrm{CH}_{3}\right) 2912 ; v(\mathrm{C}=\mathrm{C})$ $1594,1571,1536,1482,1465 ; v(\mathrm{C}=\mathrm{N}) 1440,1398,1379$, $1293,1285,1247 ; \delta\left(\mathrm{CH}_{3}\right) 1353 ; \mathrm{o}(\mathrm{C}-\mathrm{H}) 1185,1154,1095$, 1072, 1019; $\gamma(\mathrm{C}-\mathrm{H})$ 918, 830, 807, 798, 792, 781, 719, 658, $651 \mathrm{~cm}^{-1}$. Anal. Calcd. (\%) for $\left[\mathrm{Mn}\left(\mathrm{C}_{32} \mathrm{H}_{24} \mathrm{~N}_{6}\right) \mathrm{Br}_{2}\right.$ ] 
(707.32) : C, 54.34; H, 3.42; N, 11.88. Found: C, 54.28; $\mathrm{H}, 3.47$; N, 11.90 .

$\left[\mathrm{Mn}_{2}(\mathbf{L})\left(\mathrm{NO}_{3}\right)_{4}\right]$ 3: Pale yellow complex was obtained with $72 \%$ yield. ESI-MS: $\mathrm{m} / \mathrm{z}(\%)=609(10)$ $\left[\mathrm{Mn}(\mathbf{L})\left(\mathrm{NO}_{3}\right)\right]^{+}, 399(10)\left[\mathrm{Mn}_{2}(\mathbf{L})\left(\mathrm{NO}_{3}\right)_{2}\left(\mathrm{H}_{2} \mathrm{O}\right)_{4}\right]^{2+}$, 381 (5) $\left[\mathrm{Mn}_{2}(\mathbf{L})\left(\mathrm{NO}_{3}\right)_{2}\left(\mathrm{H}_{2} \mathrm{O}\right)_{2}\right]^{2+}, 372(10)\left[\mathrm{Mn}_{2}(\mathbf{L})\right.$ $\left.\left(\mathrm{NO}_{3}\right)_{2}\left(\mathrm{H}_{2} \mathrm{O}\right)\right]^{2+}$. IR $(\mathrm{KBr}): \mathrm{v}=\mathrm{v}(\mathrm{C}-\mathrm{H})_{\mathrm{ar}} 3097,3072,3055$; $v_{\mathrm{as}}\left(\mathrm{CH}_{3}\right) 2971 ; v_{\mathrm{s}}\left(\mathrm{CH}_{3}\right) 2926 ; \mathrm{v}(\mathrm{C}=\mathrm{C})$ 1596, 1572, 1538, 1486,$1469 ; v(\mathrm{C}=\mathrm{N}) 1384,1363,1303,1247 ; v_{\mathrm{as}}\left(\mathrm{NO}_{2}\right)$ $1445, v_{\mathrm{s}}\left(\mathrm{NO}_{2}\right)$ 1297; $\mathrm{Q}(\mathrm{C}-\mathrm{H})$ 1182, 1077, 1020; $\gamma(\mathrm{C}-\mathrm{H})$ 921, 834, 810, 796, 764, 701, $658 \mathrm{~cm}^{-1}$. Anal. Calcd. (\%) for $\left[\mathrm{Mn}_{2}\left(\mathrm{C}_{32} \mathrm{H}_{24} \mathrm{~N}_{6}\right)\left(\mathrm{NO}_{3}\right)_{4}\right](850.47)$ : C, 45.19; H, 2.84; $\mathrm{N}, 16.47$. Found: C, 54.22; H, 2.81; N, 16.45 .

$\left[\mathrm{Co}_{3}(\mathbf{L})_{2}\left(\mathrm{H}_{2} \mathrm{O}\right)_{2}\left(\mathrm{CH}_{3} \mathrm{CN}\right)_{4}\right]\left(\mathrm{ClO}_{4}\right)_{6}$ 7: Yellow solid was isolated with $74 \%$ yield. ESI-MS: m/z (\%) $=527(15)\left[\mathrm{Co}_{3}(\mathbf{L})_{2}\left(\mathrm{ClO}_{4}\right)_{3}\left(\mathrm{CH}_{3} \mathrm{CN}\right)_{3}\right]^{3+}, 515$ (75) $[\mathrm{Na}(\mathbf{L})]^{+}, 493(25)[\mathbf{L}+\mathrm{H}]^{+}, 486(5)\left[\mathrm{Co}_{3}(\mathbf{L})_{2}\left(\mathrm{ClO}_{4}\right)_{3}\right]^{3+}$, 380 (10) $\left[\mathrm{Co}_{3}(\mathbf{L})_{2}\left(\mathrm{ClO}_{4}\right)_{2}\left(\mathrm{CH}_{3} \mathrm{CN}\right)_{4}\right]^{4+}, \quad 370$ (10) $\left[\mathrm{Co}_{3}(\mathrm{~L})_{2}\left(\mathrm{ClO}_{4}\right)_{2}\left(\mathrm{CH}_{3} \mathrm{CN}\right)_{3}\right]^{4+}, 350$ (5) $\left[\mathrm{Co}_{3}(\mathbf{L})_{2}\left(\mathrm{ClO}_{4}\right)_{2}\left(\mathrm{CH}_{3} \mathrm{CN}\right)\right]^{4+}, 285(10)\left[\mathrm{Co}_{3}(\mathbf{L})_{2}\left(\mathrm{ClO}_{4}\right)\right.$ $\left.\left(\mathrm{CH}_{3} \mathrm{CN}\right)_{4}\right]^{5+}, 252(5)\left[\mathrm{Co}_{3}(\mathbf{L})_{2}\left(\mathrm{ClO}_{4}\right)\right]^{5+}, 220(5)$ $\left[\mathrm{Co}_{3}(\mathbf{L})_{2}\left(\mathrm{CH}_{3} \mathrm{CN}\right)_{4}\right]^{6+}, 207$ (10) $\left[\mathrm{Co}_{3}(\mathbf{L})_{2}\left(\mathrm{CH}_{3} \mathrm{CN}\right) 2\right]^{6+}$, $193(10)\left[\mathrm{Co}_{3}(\mathbf{L})_{2}\right]^{6+}$. IR $(\mathrm{KBr}): \mathrm{v}=\mathrm{v}(\mathrm{C}-\mathrm{H})_{\mathrm{ar}} 3068$; $v_{\mathrm{s}}\left(\mathrm{CH}_{3}\right)$ 2927; v $(\mathrm{C}=\mathrm{C}) 1599,1572,1536,1487,1469$; $v(\mathrm{C}=\mathrm{N})$ 1394, 1384, 1363, 1297, 1249; $\delta\left(\mathrm{CH}_{3}\right)$ 1328; $\mathrm{Q}(\mathrm{C}-\mathrm{H})$ 1141, 1121; $v_{\mathrm{as}}(\mathrm{Cl}-\mathrm{O}) 1087 ; \delta_{\mathrm{as}}(\mathrm{O}-\mathrm{Cl}-\mathrm{O})$ 626; $\gamma(\mathrm{C}-\mathrm{H})$ 1028, 1011, 941, 794, 704, $658 \mathrm{~cm}^{-1}$. Anal. Calcd. $(\%)$ for $\left[\mathrm{Co}_{3}\left(\mathrm{C}_{32} \mathrm{H}_{24} \mathrm{~N}_{6}\right)_{2}\left(\mathrm{H}_{2} \mathrm{O}\right)_{2}\left(\mathrm{CH}_{3} \mathrm{CN}\right)_{4}\right]\left(\mathrm{ClO}_{4}\right)_{6}$ (1958.89): C, 44.15; H, 3.29; N, 11.44. Found: C, 44.19; H, 3.31; N, 11.42 .

$\left[\mathrm{Cd}(\mathbf{L}) \mathrm{Br}_{2}\right]$ 8: Yellowish solid was isolated with $67 \%$ yield. ESI-MS: m/z $(\%)=684(30)[\mathrm{Cd}(\mathbf{L}) \mathrm{Br}]^{+}, 493(60)$ $[\mathbf{L}+\mathrm{H}]^{+}, 302(20)[\mathrm{Cd}(\mathbf{L})]^{2+}$. IR $(\mathrm{KBr}): v=v(\mathrm{C}-\mathrm{H})_{\mathrm{ar}}$ 3086, 3030; v $\left(\mathrm{CH}_{3}\right)$ 2969; $v_{\mathrm{s}}\left(\mathrm{CH}_{3}\right) 2921 ; \mathrm{v}(\mathrm{C}=\mathrm{C}) 1592$, 1571, 1538, 1480, 1467; v(C=N) 1449, 1393, 1350, 1285, 1268,$1255 ; \delta\left(\mathrm{CH}_{3}\right) 1349 ; \mathrm{Q}(\mathrm{C}-\mathrm{H}) 1186,1159,1101,1077$, 1014; $\gamma(\mathrm{C}-\mathrm{H})$ 879, 831, 826, 807, 793, 767, 732, 701, 657, $650 \mathrm{~cm}^{-1}$. Anal. Calcd. $(\%)$ for $\left[\mathrm{Cd}\left(\mathrm{C}_{32} \mathrm{H}_{24} \mathrm{~N}_{6}\right) \mathrm{Br}_{2}\right]$ (764.79) : C, 50.25; H, 3.16; N, 10.99. Found: C, 50.28; $\mathrm{H}, 3.18 ; \mathrm{N}, 10.97 \%$.

$\left[\mathrm{Cd}_{2}(\mathbf{L})\left(\mathrm{NO}_{3}\right)_{4}\right]$ 9: White solid was isolated with $62 \%$ field. ESI-MS: $\mathrm{m} / \mathrm{z}(\%)=902(10)\left[\mathrm{Cd}_{2}(\mathbf{L})\left(\mathrm{NO}_{3}\right)_{3}\right]^{+}$, 666 (20) $\left[\mathrm{Cd}(\mathbf{L})\left(\mathrm{NO}_{3}\right)\right]^{+}, 493(50)[\mathbf{L}+\mathrm{H}]^{+}, 302(30)$ $[\mathrm{Cd}(\mathbf{L})]^{2+}$. IR $(\mathrm{KBr}): v=v(\mathrm{C}-\mathrm{H})_{\mathrm{ar}} 3099,3052 ; v_{\mathrm{as}}\left(\mathrm{CH}_{3}\right)$ 2972; $v_{\mathrm{s}}\left(\mathrm{CH}_{3}\right)$ 2926; $v(\mathrm{C}=\mathrm{C})$ 1592, 1574, 1540, 1475, 1466; $v(\mathrm{C}=\mathrm{N}) 1384,1273 ; v_{\text {as }}\left(\mathrm{NO}_{2}\right) 1444, v_{\mathrm{s}}\left(\mathrm{NO}_{2}\right) 1297 ; \mathrm{Q}(\mathrm{C}-\mathrm{H})$ 1182, 1147, 1077, 1022; $\gamma(\mathrm{C}-\mathrm{H})$ 921, 837, 810, 797, 763, $702,659,652 \mathrm{~cm}^{-1}$. Anal. Calcd. $(\%)$ for $\left[\mathrm{Cd}_{2}\left(\mathrm{C}_{32} \mathrm{H}_{24} \mathrm{~N}_{6}\right)\right.$ $\left.\left(\mathrm{NO}_{3}\right)_{4}\right]$ (965.41): C, 39.81; H, 2.51; N, 14.51. Found: C, 39.84; H, 2.53; N, 14.53.

\section{CONCLUSIONS}

Luminescence properties of supramolecular complexes with pyridine-bipyridine hybrid ligand strongly depend on the structure of complexes and the kind of metal ions. The best luminescence properties exhibit complexes in which (i) metal ion is not an inherent emission quencher (Mn(II) and $\mathrm{Cd}(\mathrm{II})$ ) and (ii) counterions are perchlorate and nitrate anions. Such complexes are interesting luminescent materials for the construction organic light-emitting diodes and luminescent sensors.

\section{ACKNOWLEDGEMENTS}

This research was carried out as a part of the Polish National Science Center project (Grant No. 2011/03/B/ ST5/01036).

\section{LITERATURE CITED}

1. Cooke, M.W. \& Hanan, G.S. (2007). Luminescent polynuclear assemblies. Chem. Soc. Rev. 36, 1466-1476. DOI: 10.1039/ b609200b.

2. Pucci, D., Crispini, A., Ghedini, M., Szerb, E.I. \& La Deda, M. (2011). 2,2'-Biquinolines as test pilots for tuning the colour emission of luminescent mesomorphic silver(I) complexes. Dalton Trans. 40, 4614-4622. DOI: 10.1039/c0dt01842b.

3. Winter, A., Friebe, Ch., Chiper, M., Schubert, U.S., Presselt, M., Dietzek, B., Schmitt, M. \& Popp, J. (2009). Synthesis, characterization, and electro-optical properties of $\mathrm{Zn}(\mathrm{II})$ complexes with $\pi$-conjugated terpyridine ligands. Chem. Phys. Chem., 10, 787-798. DOI: 10.1002/cphc.200800714.

4. Zhang, L., Chen, P. \& Lin, L. (2013). Preparation of luminescent zinc(II) coordination polymer and its encapsulation in the nanoporous channels. Inorg. Chem. Commun. 27, 156-158. DOI: 10.1016/j.inoche.2012.11.002.

5. Winter, A., Friebe, Ch., Hager, M.D. \& Schubert, U.S. (2008). Advancing the solid state properties of metallo-supramolecular materials: poly $(\varepsilon$-caprolactone $)$ modified $\pi$-conjugated bis(terpyridine)s and their $\mathrm{Zn}(\mathrm{II})$ based metallo-polymers. Macromol. Rapid Commun. 29, 1679-1686. DOI: 10.1002/ marc.200800377.

6. Wałęsa-Chorab, M., Stefankiewicz, A.R., Ciesielski, D., Hnatejko, Z., Kubicki, M., Kłak, J., Korabik, M.J. \& Patroniak V. (2011). New mononuclear manganese(II) and zinc(II) complexes with a terpyridine ligand: Structural, magnetic and spectroscopic properties. Polyhedron, 30, 730-737. DOI: $10.1016 /$ j.poly.2010.12.032.

7. Béziau, A., Baudron, S.A., Guenet, A. \& Hosseini, M.W. (2013). Luminescent coordination polymers based on self-assembled cadmium dipyrrin complexes. Chem. Eur. J., 19, 3215-3223. DOI: 10.1002/chem.201203133.

8. Ge, S.Z., Liu, Q., Deng, S., Sun, Y.Q. \& Chen, Y.P. (2013). Two new luminescent cadmium thiolato-carboxylates with 2,2'-bipyridine. J. Inorg. Organomet. Polym., 23, 571-578. DOI: 10.1007/s10904-012-9814-5.

9. Roy, S., Sarkar, B.N., Bhar, K., Satapathi, S., Mitra, P. \& Ghosh, B.K. (2013). Syntheses, structures and luminescence behaviors of zinc(II) complexes containing a tetradentate Schiff base: Variation in nuclearity and geometry with the change of halide/pseudohalide/carboxylate and counter anion. J. Mol. Struct., 1037, 160-169. DOI: 10.1016/j.molstruc.2012.12.018.

10. Zhou, X., Jin, X., Li, D. \& Wu, X. (2011). Selective detection of zwitterionic arginine with a new $\mathrm{Zn}$ (II)-terpyridine complex: potential application in protein labeling and determination. Chem. Commun. 47, 3921-3923. DOI: 10.1039/ c0cc05771a.

11. Das, P., Ghosh, A., Kesharwani, M.K., Ramu, V., Ganguly B. \& Das, A. (2011). Zn(II)-2,2':6',2'-Terpyridine-Based Complex as Fluorescent Chemosensor for PPi, AMP and ADP. Eur. J. Inorg. Chem. 3050-3058. DOI: 10.1002/ejic.201100125.

12. Wałęsa-Chorab, M., Gorczyński, A., Kubicki, M., Korabik, M. \& Patroniak, V. (2013). Mono-, di- and trinuclear complexes of bis(terpyridine) ligand: synthesis, crystal structures and magnetic properties. Polyhedron, 54, 260-271. DOI: 10.1016/j. poly.2013.02.054.

13. Wałęsa-Chorab, M., Patroniak, V., Kubicki, M., Kądziołka, G., Przepiórski, J. \& Michalkiewicz, B. (2012). Synthesis, structure, and photocatalytic properties of new dinuclear helical complex of silver(I) ions. J. Catal. 291, 1-8. DOI: 10.1016/j. jcat.2012.03.025. 
14. Yam, V.W.W., Chan, Kenneth, H.Y., Wong, Keith, M.C. \& Zhu, N. (2005). Luminescent platinum(II) terpyridyl complexes: effect of counter ions on solvent-induced aggregation and color changes. Chem. Eur. J. 11, 4535-4553. DOI: 10.1002/ chem.200500106.

15. Ji, S., Wu, W., Wu, W., Song, P., Han, K., Wang, Z., Liu, S., Guo, H. \& Zhao, J. (2010). Tuning the luminescence lifetimes of ruthenium(II) polypyridinecomplexes and its application in luminescent oxygen sensing. J. Mater. Chem. 20, 1953-1963. DOI: 10.1039/B916468E.

16. Alcoc, N.W., Barker, P.R., Haider, J.M., Hannon, M.J., Painting, C.L., Pikramenou, Z., Plummer, E.A., Rissanen, K. \& Saarenketo, P. (2000). Red and blue luminescent metallo-supramolecular coordination polymers assembled through $\pi-\pi$ interactions. J. Chem. Soc. Dalton Trans. 1447-1461. DOI: $10.1039 / \mathrm{b} 000871 \mathrm{k}$.

17. Zheng, S.L. \& Chen, X.M. (2004). Recent advances in luminescent monomeric, multinuclear, and polymeric $\mathrm{Zn}$ (II) and Cd(II) coordination complexes. Aust. J. Chem. 57, 703-712. DOI: $10.1071 / \mathrm{CH} 04008$. 